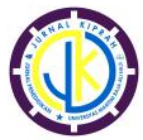

http://ojs.umrah.ac.id/index.php/kiprah

\title{
Peningkatkan Aktivitas dan Hasil Belajar Bahasa Inggris Melalui Running Dictation pada Peserta didik Kelas VIII SMP Negeri Mautenda
}

\author{
Yuliani Sepe Wangge ${ }^{1 *}$, Wilhelmina Donata Timu ${ }^{2}$ \\ ${ }^{1}$ Pendidikan Guru Sekolah Dasar, Universitas Flores, Ende, Indonesia \\ ${ }^{2}$ SMP Negeri Mautenda, Ende, Indonesia \\ Pengiriman: 12/02/2020; Diterima: 29/05/2020; Publikasi: 30/06/2020 \\ DOI: https://doi.org/10.31629/kiprah.v8i1.2033
}

\begin{abstract}
Abstrak
Penelitian ini dilakukan di SMP Negeri Mautenda. Permasalahan yang dihadapi adalah rendahnya aktivitas dan hasil belajar bahasa Inggris. Berdasarkan permasalahan tersebut, tujuan penelitian ini adalah untuk meningkatkan aktivitas dan hasil belajar bahasa Inggris melalui running dictation pada siswa kelas VIII di SMP Negeri Mautenda, Kecamatan Wewaria, Kabupaten Ende. Penelitian ini merupakan Penelitian Tindakan Kelas (PTK). Penelitian dilakukan selama dua siklus. Subjek penelitian adalah siswa kelas VIII di SMP Negeri Mautenda yang berjumlah 20 orang. Teknik pengumpulan data dilakukan melalui observasi, tes dan dokumentasi. Data dianalisis dengan deskriptif kualitatif dan kuantitatif. Hasil penelitian menunjukkan bahwa aktivitas belajar melalui running dictation mengalami peningkatan dari siklus I dengan rata-rata sebesar 58\% meningkat menjadi 77,14\% pada siklus II. Peningkatan aktivitas belajar berpengaruh pada meningkatnya hasil belajar. Siklus I rata-rata hasil belajar sebesar 64 meningkat menjadi 78 pada siklus II. Berdasarkan hasil tersebut dapat disimpulkan bahwa penggunaan running dictation dapat meningkatkan aktivitas dan hasil belajar bahasa Inggris.
\end{abstract}

Kata Kunci: aktivitas belajar; hasil belajar; running dictation

\begin{abstract}
This research was conducted in SMP Negeri Mautenda. The problems faced were the low activity and the results of learning English. Based on the problem, the purpose of this research is to increase the activity and results of learning English through running dictation in VIIIc students in SMP Negeri Mautenda, Wewaria District Ende Regency. This research is a class action research (CAR). Research is conducted over two cycles. The research subject is a VIIIc class student of 20 people. Data collection techniques are conducted through observation, tests and documentation. Data is analyzed with qualitative and quantitative descriptive. The results showed that learning activity through running dictation increased from cycle I by an average of 58\% increased to $77.14 \%$ in cycle II. The enhancement of learning activity affects the increasing learning outcomes. In cycle I the average grade value of 64 is increased to 78 in cycle II. Based on the results it can be concluded that the use of running dictation can increase the activity and outcome of English learning.
\end{abstract}

Keywords: learning activity; learning outcomes; running dictation

\section{PENDAHULUAN}

Pembelajaran bahasa khususnya bahasa Inggris memiliki tujuan agar para siswa terampil berbahasa yang mencakup keterampilan mendengar, berbicara, membaca ,dan menulis. Megawati (2016) menyatakan, ada tiga elemen dalam mempelajari bahasa Inggris yakni kosakata atau vocabulary, 
pelafalan atau pronounciation, dan struktur bahasa atau grammar. Menurut Fransiska (2013), vocabulary memegang peranan yang sangat penting dalam penguasaan empat keterampilan berbahasa. Sejalan dengan Fransiska, Wangge (2019) menyatakan bahwa kemampuan dalam menguasai kosakata merupakan dasar dalam mempelajari bahasa Inggris baik itu dari aspek membaca, menyimak, berbicara, maupun menulis.

Menurut Nurgiantoro dalam Rikmasari (2018), kosakata bahasa Inggris merupakan salah satu komponen penting yang perlu dikuasai agar mampu berbahasa inggris dengan baik. Penguasaan kosakata dapat dibedakan ke dalam penguasaan yang bersifat reseptif dan produktif, yaitu kemampuan untuk memahami dan mempergunakan kosakata. Kemampuan memahami terlihat dalam kegiatan membaca dan menyimak, sedangkan kemampuan mempergunakan tampak dalam kegiatan menulis dan berbicara

Hasil observasi di kelas VIIIc SMP Negeri Mautenda pada pembelajaran bahasa Inggris, peneliti menemukan bahwa permasalahan yang dihadapi di kelas tersebut adalah kurang maksimalnya aktivitas belajar dan rendahnya hasil belajar bahasa Inggris. Diedrich (dalam Sardiman, 2011) menggolongkan aktivitas belajar menjadi 8 aktivitas: 1) visual activities, yang termasuk didalamnya misalnya membaca, memperhatikan gambar, demonstrasi, percobaan, dan pekerjaan orang lain; 2) oral activities, seperti menyatakan, merumuskan, bertanya, memberi saran, mengeluarkan pendapat, mengadakan wawancara, diskusi, dan interupsi; 3) listening acivities, sebagai contoh mendengarkan yaitu uraian, percakapan, diskusi, musik, dan piano; 4) writing activities, seperti misalnya menulis cerita, karangan, laporan, angket, dan manyalin; 5) drawing activities, misalnya menggambar, membuat grafik, peta, dan diagram; 6) motor activities, yang dimaksud di dalamnya antara lain, melakukan percobaan, membuat konstruksi, model mereparasi, bermain, berkebun, dan berternak; 7) mental activities, sebagai contoh misalnya, menanggapi, mengingat, memecahkan soal, menganalisis, melihat hubungan, dan mengambil kesimpulan; dan 8) emotional activities, seperti misalnya menaruh minat merasa bosan, gembira, bersemangat, bergairah, berani, tenang, dan gugup.

Mengacu pada teori aktivitas Diedrich, peneliti menemukan bahwa kurang maksimalnya aktivitas belajar terlihat pada saat proses pembelajaran. Saat proses pembelajaran berlangsung, aktivitas oral seperti kegiatan bertanya dan mengeluarkan pendapat di dalam kelas hanya dilakukan oleh sebagian peserta didik. Motor activities seperti pembelajaran melalui permainan belum diterapkan. Mental activities seperti mengingat, melihat hubungan kata demi kata, menanggapi dan memecahkan soal belum terlaksana dengan maksimal. Emotional activities, seperti menaruh minat, bergairah, berani, dan sikap tenang hanya beberapa peserta didik saja. Kurang maksimalnya aktivitas belajar berpengaruh pada hasil belajar yang diperoleh peserta didik.

Hasil belajar menurut Sudjana dalam MS (2017) adalah kemampuan yang dimiliki peserta didik setelah menerima pengalaman belajar. Sejalan dengan Sudjana, Iskandarwassid dalam Muthoharoh (2017) mengatakan bahwa hasil belajar adalah segala hal yang diterima peserta didik setelah mengikuti materi atau mata pelajaran tertentu. Hasil belajar diperoleh dari tes. Tujuan utama dari tes adalah untuk mengetahui tingkat keberhasilan mereka setelah mengikuti pembelajaran. Hasil belajar dalam penelitian ini dilihat berdasarkan hasil tes yang dilakukan guru pada proses pembelajaran. Hasilnya dari 20 orang peserta didik hanya 8 orang saja yang tuntas, 12 orang lainnya memperoleh nilai di bawah KKM 65.

Berdasarkan hasil observasi tersebut, peneliti menemukan bahwa, permasalahan kurangnya aktivitas belajar disebabkan karena kurang bervariasinya model, metode, dan strategi pembelajaran yang digunakan, sehingga berdampak pada kurangnya motivasi 
belajar bahasa Inggris khususnya pada aspek penguasaan kosakata yang belum maksimal. Hal ini akhirnya berpengaruh pada hasil belajar. Dari permasalah tersebut di atas, maka selain model dan metode pembelajaran yang bervariasi, guru juga perlu menerapkan strategi yang dapat membantu peserta didik agar memiliki keterampilan bahasa Inggris dengan baik. Salah satu strategi pembelajaran yang dapat digunakan untuk membantu peserta didik meningkatkan kemampuan berbahasa Inggris adalah strategi running dictation.

Menurut Hess (Rikmasari dkk, 2018) "Running Dictation is the technique where the students works in group to dictate the sentence, there is the runner and the writer in each group. The students as the runner must run to some place where the sentence have been prepared by teacher and back to his/her group to dictate the sentence, the the writer must write down what they heard as accurately as possible"

Running Dictation adalah strategi (dalam pembelajaran) yang mana peserta didik bekerja dalam kelompok untuk mendikte kalimat, ada yang sebagai pelari dan sebagai penulis dalam setiap kelompok. Peserta didik sebagai pelari harus berlari ke tempat di mana kalimat atau teks yang sudah disiapkan guru dan kembali ke kelompoknya untuk mendikte kalimat, penulis harus menulis apa yang mereka dengar seakurat mungkin. Cohan dalam Zulraudah (2014) mengatakan bahwa running dictation merupakan aktivitas yang dilakukan dalam kelompok kecil yang bisa menjadi satu alternatif dalam proses belajar yang baik karena memberikan nilai tambah bagi peserta didik dalam aspek sosial seperti interaksi antara siswa di kelas.

$$
\text { Milne dalam Riyanti }
$$

mengatakan bahwa dikte atau dictation merupakan alat dalam pembelajaran bahasa yang sudah ada sejak lama. Dia yakin bahwa banyak di antara kita pernah melakukan kegiatan dikte di kelas. Running dictation merupakan kegiatan mendikte yang tidak sama seperti kegiatan mendikte yang diberikan guru. Guru sebagai model dan memberikan pengajaran di depan kelas. Menurut Milne kegiatan running dictation ini jauh lebih menarik. Menurut Wright et al. (2006) ada beberapa langkah dalam menjalankan strategi Running Dictation, yaitu:

1) Tampilkan satu atau lebih salinan teks di dinding kelas atau di atas meja.

2) Bagilah peserta didik menjadi pasanganpasangan dan memiliki masing-masing pasangan memutuskan siapa yang akan menjadi siswa A dan siapa yang akan menjadi siswa B.

3) Jelaskan aturan permainan sebagai berikut: siswa A berlari menuju teks, membacanya dan mencoba menghapal sebanyak mungkin sebelum berlari kembali ke siswa B. siswa A harus mendikte apa yang mereka ingat dari teks ke siswa B, yang harus mencatat secara tertulis. Siswa A dapat berjalan ke teks sesering yang diperlukan untuk menyelesaikan mendikte seluruh teks. Mintalah setiap tim untuk membacakan teks.

4) Memuji pasangan pertama untuk menyelesaikan tanpa kesalahan.

Strategi running dictation ini melatih peserta didik untuk lebih bertanggung jawab atas pesan yang didapat. Peserta didik bekerja berpasangan dalam kelompok kecil dan belajar berinteraksi dengan teman sebaya. Kegiatan ini dapat memotivasi dan menyenangkan peserta didi karena belajar dengan teman sebaya lebih mendukung peserta didik mudah mengerti tentang materi yang mereka pelajari (Zulkifli, 2014).

Penelitian yang menggunakan running dictation pernah dilakukan oleh Zulkifli (2014), Zulraudah (2014), Sardju (2017), Riyanti (2017), dan Rikmasari (2018). Berdasarkan hasil penelitian dari peneliti terdahulu diketahui bahwa penelitian menggunakan running dictation dapat meningkatkan keterampilan berbahasa Inggris. Mengacu pada hasil tersebut, maka peneliti melakukan penelitian ini menggunakan strategi running dictataion.

Adapun perbedaan penelitian ini dari 
penelitian terdahulu adalah penelitian terdahulu hanya fokus pada salah satu aspek keterampilan berbahasa saja, ada yang meneliti tentang keterampilan menulis, keterampilan berbicara dan ada yang hanya fokus pada penguasaan kosakata saja. Namun, penelitian yang dilakukan oleh peneliti di SMP Negeri 1 Mautenda, fokus pada aktivitas belajar dan hasil belajar. Hasil belajar diukur berdasarkan keempat keterampilan berbahasa Inggris yaitu keterampilan menyimak, keterampilan berbicara, keterampilan membaca dan keterampilan menulis serta penguasaan kosakata.

Hal ini dilakukan peneliti berdasarkan permasalahan yang ditemukan selama observasi awal. Tujuan dari penelitian ini adalah untuk meningkatkan aktivitas dan hasil belajar bahasa Inggris melalui running dictation pada peserta didik kelas VIII SMP Negeri Mautenda.

\section{METODE PENELITIAN}

Penelitian ini merupakan penelitian tindakan kelas (PTK) yang menggunakan model kemmis \& MC Taggart yang terdiri dari 4 tahapan yaitu tahap perencanaan, tindakan, observasi dan refleksi. Perencanaan adalah segala sesuatu yang disiapkan yang akan dilakukan pada tahap tindakan. Pada tahap tindakan dilaksanakan bersamaan dengan tahap observasi. Data hasil dari observasi inilah yang akan dianalisis dan kegiatan analisis ini biasa disebut sebagai tahap refleksi (Prihantoro dan Hidayat, 2019).

Penelitian ini bertujuan untuk mendeskripsikan apakah penggunaan running dictation dapat meningkatkan aktivitas dan hasil belajar bahasa Inggris Peserta didik kelas IV. Penelitian ini berlangsung pada bulan Oktober 2019. Subjek penelitian ini adalah peserta didik kelas VIIIc SMP Negeri Mautenda yang berjumlah 20 orang. Teknik pengumpulan data dilakukan dengan cara observasi, tes, dan dokumentasi. Data dianalisis dengan cara deskriptif kualitatif dan kuantitatif.

\section{Keterlaksanaan dalam menerapkan strategi Running Dictation}

Data diperoleh dari pemberian skor oleh observer terhadap penerapan strategi running dictation yang diterapkan peneliti dimana peneliti bertindak sebagai guru. data hasil observasi dianalisis dengan menggunakan rumus sebagai berikut:

$$
\begin{aligned}
& \mathrm{F} \\
& \begin{array}{l}
\mathrm{P}=-\mathrm{X} 100 \% \\
\mathrm{~A}
\end{array} \\
& \text { Keterangan: } \\
& \mathrm{P} \quad=\text { Persentase keterlaksanaan strategi } \\
& \quad \text { running dictation } \\
& \mathrm{F}=\text { Jumlah skor yang diperoleh } \\
& \mathrm{A}=\text { Jumlah skor maksimal }
\end{aligned}
$$

\section{Aktivitas Belajar Peserta Didik}

Lembar observasi berisi butir-butir aktivitas belajar peserta didik yang harus tampak dalam pembelajaran melalui strategi running dictation dan masing-masing butir diberi skor, kemudian diolah sehingga diperoleh persentase dengan menggunakan rumus.

$$
\mathrm{P}=-\mathrm{F} \times 100 \%
$$$$
\text { A }
$$

Keterangan

$\mathrm{P}=$ Persentase aktivitas

$\mathrm{F}=$ Jumlah skor yang diperoleh

A = Jumlah skor maksimal

\section{Persentase keberhasilan perseorangan}

Adapun bentuk analisis persentase ketuntasan belajar siswa secara perseorangan adalah sebagai berikut:

$$
\begin{aligned}
& \mathrm{F} \\
& \mathrm{P}=-\mathrm{A} \times 100 \% \\
& \mathrm{~A} \\
& \text { Keterangan } \\
& \mathrm{P}=\text { Persentase keberhasilan } \\
& \mathrm{F}=\text { Jumlah skor yang diperoleh } \\
& \mathrm{A}=\text { Jumlah skor maksimal }
\end{aligned}
$$

\section{Persentase klasikal}

Persentase klasikal dihitung dengan 
kriteria ketuntasan kelompok (klasikal), adalah siswa yang dianggap telah tuntas belajarnya atau dalam arti siswa yang nilai tesnya telah mencapai atau lebih dari nilai KKM yang telah ditetapkan dihitung dengan menggunakan rumus:

$$
\begin{gathered}
\mathrm{A} \\
\mathrm{K}=-\mathrm{x} 100 \%
\end{gathered}
$$$$
\text { B }
$$

Keterangan

$\mathrm{K}=$ Persentase keberhasilan klasikal

$\mathrm{A}=$ Jumlah siswa yang memperoleh nilai $\geq 65$

$\mathrm{B}=$ Jumlah seluruh siswa

(dimodifikasi dari Arikunto, 2010: 246)

Keberhasilan tindakan ditandai dengan adanya pencapaian ketuntasan belajar. Apabila 85\% peserta didik telah mencapai KKM 65, maka tidak perlu dilanjutkan ke siklus berikutnya.

\section{HASIL DAN PEMBAHASAN}

Penelitian ini dilakukan dalam dua siklus. Adapun hasil aktivitas belajar pada penelitian ini dapat dilihat pada tabel aktivitas belajar siklus I dan siklus II berikut ini

Tabel 1 Aktivitas Belajar Siswa Siklus I dan Siklus

\begin{tabular}{|c|c|c|c|}
\hline No & Aspek Aktivitas & Siklus I & Siklus II \\
\hline 1 & Aktivitas Visual & 58,3 & 75 \\
\hline 2 & Aktivitas Oral & 51,6 & 73,3 \\
\hline 3 & Aktivitas Mental & 63,3 & 80 \\
\hline 4 & Aktivitas Emotional & 53,3 & 70 \\
\hline 5 & Aktivitas Motor & 60 & 81,6 \\
\hline 6 & Aktivitas endengar & 55 & 76,6 \\
\hline \multirow[t]{3}{*}{7} & Aktivitas Menulis & 65 & 83,3 \\
\hline & Rata-rata & 58 & 77,14 \\
\hline & Kriteria & $\begin{array}{l}\text { Cukup } \\
\text { Baik }\end{array}$ & Baik \\
\hline
\end{tabular}
II

menunjukan bahwa pembelajaran menggunakan strategi running dictation dapat meningkatkan aktivitas belajar bahasa Inggris pada peserta didik kelas VII. Hal ini dapat dilihat dari persentase pada siklus I dengan rata-rata sebesar 58 dengan kategori cukup baik menjadi 77,14 pada siklus II dengan kategori baik. Meningkatnya aktivitas belajar berpengaruh pada meningkatnya hasil belajar. Siklus I nilai rata-rata kelas sebesar 64 dengan persentase ketuntasan klasikal mencapai $40 \%$ meningkat menjadi $100 \%$ dengan nilai ratarata sebesar 78 .

Peningkatan aktivitas belajar bahasa Inggris pada tabel 1 merupakan hasil dari pelaksanaan penelitian yang menggunakan strategi running dictation. Langkah-langkah penerapan teknik running dictation pada pembelajaran bahasa Inggris melalui empat tahap yaitu perencanaan, pelaksanaan, observasi, dan refleksi, yang dilakukan selama dua siklus. Tahap pertama dilakukan dengan mempersiapkan perangkat pembelajaran yang menggunakan strategi running dictation, setelah semua persiapan dilakukan, dilanjutkan pada tahap dua yaitu pelaksanaan.

Pada tahap pelaksanaan, peneliti melaksanakan pembelajaran dengan cara memperkenalkan kosakata bahasa Inggris dari teks yang telah disiapkan kepada peserta didik dan menerapkan kosakata yang dipelajari peserta didik melalui teknik running dictation. Siklus I siswa dibagi dalam 5 kelompok yang beranggotakan 4 orang. Setiap anggota ada yang berperan sebagai runner dan sebagai writer. Dalam kegiatan ini, peserta didik bergantian menjadi runner dan writer.

Kegiatan dalam running dictation ini adalah peserta didik yang sebagai runner, berlari ke arah teks yang disiapkan guru dan membaca teks serta berusaha mengingatnya dan kembali ke teman kelompoknya dan mendiktekan teks yang sudah dibaca tadi dan peserta didik sebagai writer menulis kembali teks yang didiktekan temannya. Kegiatan ini dilakukan berulang-ulang sampai mereka selesai menulis teks yang didiktekan teman kelompoknya. Setelah selesai mereka membacakan teks yang sudah mereka tulis. Peneliti memberikan pujian kepada kelompok yang pertama menyelesaikan tanpa ada kesalahan.

Tahap observasi dilakukan selama proses pembelajaran berlangsung, yaitu dari awal hingga akhir pembelajaran. Ada satu observer yang mengamati kegiatan 
pembelajaran melalui strategi running dictation ini. Setelah pembelajaran selesai peneliti melakukan tahap berikutnya yaitu tahap refleksi.

Pada tahap refleksi siklus I ditemukan adanya kelemahan yang menghambat kegiatan pembelajaran yaitu kurang aktifnya beberapa anggota kelompok dalam kegiatan belajar melalui metode running dictation ini mereka lebih mengandalkan teman kelompoknya untuk menyelesaikan tugas mereka. Selain itu, aturan kegiatan pembelajaran yang kurang maksimal sehingga kegiatan running dictation yang terlaksana terkesan gaduh atau kurang teratur ini berdampak pada hasil belajar yang belum mencapai target yang diharapkan.

Pada siklus I, aktivitas belajar bahasa Inggris pada aspek aktivitas oral dan emotional merupakan dua aspek aktivitas belajar terendah. Berdasarkan observasi diketahui bahwa aktivitas oral seperti bertanya, mengeluarkan pendapat, dan diskusi belum terlaksana dengan maksimal. Hal tersebut dibuktikan dari persentase hasil observasi aktivitas oral hanya sebesar 51,6\%. Demikian pula pada aspek aktivitas emotional, dengan rata-rata persentase sebesar 53,3\%. Hal ini disebabkan karena masih ada beberapa peserta didik yang belum berani atau masih malu melakukan kegiatan running dictation.

Berdasarkan tabel I diketahui bahwa rata-rata aktivitas belajar peserta didik sebesar 58\% dengan kategori cukup baik, namun hasil ini belum sesuai dengan target yang ingin dicapai yaitu kategori baik. Selain aktivitas belajar, hasil belajar pada siklus I juga belum mencapai apa yang diharapkan, pada siklus I hanya 8 orang peserta didik yang tuntas dengan nilai rata-rata 64 dari 20 orang, ini berarti hanya $40 \%$ yang tuntas secara klasikal. Berdasarkan data tersebut maka penelitian dilanjutkan ke siklus II.

Tahap pembelajaran pada siklus II dilaksanakan seperti pada siklus I, namun dilakukan berdasarkan hasil refleksi siklus I. Pada tahap perencanaan siklus II, peneliti merancang perangkat pembelajaran berdasarkan hasil refleksi siklus I, pada siklus ini peneliti memutuskan menyiapkan media yang lebih menarik dan membuat aturan yang jelas tentang pelaksanaan pembelajaran menggunakan running dictation. Pada tahap ini juga, peneliti memutuskan membagi peserta didik dalam kelompok kecil sehingga pembelajaran dapat berlangsung dengan baik.

Setelah rancangan pembelajaran selesai dibuat, peneliti melanjutkan ke tahap berikutnya yaitu tahap pelaksanaan. Tahap pelaksananaan dilakukan mengacu pada rencana pelaksanaan pembelajaran. Pada tahap ini kegiatan running dictation dilakukan oleh peserta didik dalam kelompok kecil yang terdiri dari dua orang. Peneliti menyiapkan 10 teks yang sebagian ditempel di dinding dan sebagian lagi diletakan di meja guru dan meminta peserta didik berlari menuju teks yang telah disediakan kemudian membaca teks tersebut dan berusaha mengingat sebanyak mungkin isi teks tersebut lalu kembali ke teman kelompoknya dan mendiktekan teks yang sudah dibaca tadi kepada temannya untuk ditulis kembali.

Kegiatan ini dilakukan berulang-ulang sampai mereka selesai menulis dan waktu yang ditentukan oleh guru telah habis kemudian masing-masing kelompok membacakan hasil pekerjaan mereka. Guru memberikan pujian pada kelompok yang berhasil menulis teks tanpa kesalahan. Tahap observasi dilakukan bersamaan dengan tahap pelaksanaan.

Pada tahap observasi peneliti dibantu oleh dua orang observer untuk membantu peneliti mengamati aktivitas pembelajaran menggunakan strategi running dictation. aktivitas yang diamati adalah aktivitas guru dan aktivitas peserta didik. Hal ini dilakukan untuk melihat apakah guru dalam hal ini peneliti sudah melaksanakan pembelajaran sesuai dengan rencana pelaksanaan pembelajaran begitu pula dengan peserta didik.

Tahap berikutnya adalah tahap refleksi. Berdasarkan hasil pengamatan pada siklus II diketahui bahwa peneliti sudah melaksanakan pembelajaran sesuai dengan rencana pelaksanaan pembelajaran, dan pada 
saat pembelajaran peneliti sudah menjelaskan aturan pembelajaran menggunakan running dictation dengan baik, sehingga pembelajaran berjalan lancar dan kegaduhan atau keributan yang terjadi pada siklus I tidak terjadi pada siklus II. Pada siklus ini juga, peneliti memberikan motivasi ekstra pada peserta didik yang masih tampak malu-malu dalam mengikuti pembelajaran.

Tahap refleksi ditemukan bahwa aktivitas belajar bahasa Inggris sudah mengalami peningkatan dibandingkan pada siklus I hal ini dapat dilihat pada tabel 1 dimana persentase aspek aktivitas visual meningkat menjadi 75 , aspek oral 73 , aspek mental 80, aspek emotional 70, aspek motor 81 , aspek mendengar 76 , dan aspek menulis sebesar 83. Rata-rata aktivitas belajar siklus II meningkat dari 58 dengan kategori cukup baik menjadi 77,14 dengan kategori baik. Hasil belajar pada siklus II mengalami peningkatan ketuntasan klasikal dari $40 \%$ menjadi $100 \%$ dengan nilai rata-rata sebesar 78 . Perkembangan hasil dari siklus pertama dan kedua telah membuktikan adanya ketercapaian ketuntasan belajar yang diharapkan sehingga penelitian ini tidak perlu dilanjutkan ke siklus selanjutnya.

\section{KESIMPULAN}

Hasil penelitian pada siklus I dan siklus II menunjukkan bahwa penggunaan strategi running dictation dapat meningkatkan aktivitas dan hasil belajar bahasa Inggris pada peserta didik kelas VIII di SMP Negeri Mautenda, Kecamatan Wewaria, Kabupaten Ende. Pembelajaran menggunakan Running Dictation dapat meningkatkan motivasi dan aktivitas belajar peserta didik sehingga berdampak pada hasil belajar.

Saran peneliti untuk guru bahasa Inggris di SMP untuk menggunakan strategi running dictation sebagai salah satu alternatif pembelajaran di kelas. Namun, perlu diingat bahwa strategi pembelajaran ini lebih cocok diterapkan pada kelompok kecil, sehingga hasil yang diharapkan bisa maksimal.

\section{UCAPAN TERIMA KASIH}

Ucapan terima kasih ditujukan kepada ketua program studi PGSD Universitas Flores karena sudah mengizinkan peneliti melakukan penelitian di sekolah. Ucapan terima kasih selanjutnya diberikan kepada kepala sekolah dan guru bahasa Inggris SMP Negeri Mautenda karena sudah menerima, mengijinkan, dan mendukung peneliti, sehingga penelitian ini terlaksana dengan baik.

\section{REFERENSI}

Arikunto,S. (2010). Prosedur Penelitian Suatu Pendekatan Praktik. Jakarta: Rineka Cipta.

Fransiska, Irma Erviana. (2013). Penggunaan Metode Pembelajaran Make A Match dalam penguasaan vocabulary untuk meningkatkan hasil belajar siswa pada mata pelajaran bahas Inggris. Elementary School journal PGSD FIP Unimed.Vol 1, No 1. https://jurnal.unimed.ac.id/2012/index.p hp/elementary/article/view/1300

Megawati, F. (2016). Kesulitan Mahasiswa dalam mencapai pembelajaran Bahasa Inggris secara Efektif. Jurnal Pedagogia, Volume 5, no 2. https://scholar.google.co.id

Kormiana, M.S. (2017). Metode Think Pair Share (TPS) untuk Meningkatkan Hasil Belajar Bahasa Inggris Siswa Sekolah Menengah Pertama.Jurnal Ilmu Pendidikan Sosial, Sains dan Humaniora. Vol 3, No.1. Doi: https://dx.doi.org/10.24014/suara\%20gu ru.v3i1.3048

Muthoharoh, N. B.. (2017). Pengaruh Model Pembelajaran Kooperatif "Think Pair Share (TPS)" Terhadap Hasil Belajar Bahasa Inggris. Jurnal SAP. Vol 2 No 1. https://Journal.lppmunidra.ac.id/index.p $\mathrm{hp} / \mathrm{SAP} /$ article/vie/1509/1335

Prihantoro, Agung dan Hidayat, Fattah. (2019). elakukan Penelitian Tindakan Kelas. Ulumuddin: Jurnal Ilmu-ilmu Keislaman. Vol.9, No.1. https://jurnal.ucy.ac.id/index.php/agama 
_islam/index

Rikmasari, Rima. (2018). Upaya Meningkatkan Penguasaan Kosakata Melalui Metode Running Dictation Pada Mata Pelajaran Bahasa Inggris Kelas V di MIT ATTAQWA 01 Bekasi. http://jurnal.unismabekasi.ac.id/index.p hp/pedagogik/article/viewfile/1604/137 3. (diakses pada tanggal 4 Februari 2020)

Riyanti, Eka Widi. (2017). The Use Of Running Dictation Game And Rapid Writing Strategies To Improve The Student Writing Skill Of The Eight Grade Students Of MTS N Susukan In The Academic Year Of 2017/2018. http://e-

repository.perpus.iainsalatiga.ac.id/1893 I (diakses tanggal 5 Februari 2020)

Sardiman, AM. (2011). Interaksi dan Motivasi Belajar Mengajar. Jakarta: PT. Raja Grafindo Persada.

Sardju. Ida Hendryani. (2017). Peningkatan Keterampilan Berbicara Doubt Expression Melalui Model Pembelajaran Running Dictation Menggunakan Media Tegar Pada Siswa Kelas IX-6 Mts Negeri 1 Ternate Tahun Ajaran 2016/2017. Humano. Vol 8, No. 2.

http://ejournal.unkhair.ac.id/index.php/h umano/article/view/520

Wangge, Yuliani Sepe. Sar'lyyah, Nining. (2019). Permainan ular tangga Berbasis Cerita Rakyat Ende-Lio untuk Meningkatkan Kosakata Bahasa Inggris. Jurnal Pendidikan Dasar Nusantara. Vol.4, No. 2. 164-170. Doi: https://doi.org/10.29407/jpdn.v4i2.1251 7

Wright, Andrew. David, B, and Michael B. (2006). Games for Language Learning Third Edition (Cambridge Handbook for Language Teacher). Cambridge: Cambridge University Press.

Zulkifli, Nur Aisyah. (2014). Meningkatkan Kemampuan Bahasa Inggris Siswa Dengan Menggunakan Running
Dictation Melalui Materi Agama Di SD IT Al-Fittiyah Pekanbaru. Uin Sultan Syarif Kasim Riau. http://ejournal.uinsuska.ac.id/index.php/kutubkhanah/artic le/viewfile/816/776. (diakses pada tanggal 4 Februari 2020)

Zulraudah. Jufri. (2014). Teaching Writing By Using Running Dictation Activity For Elementary School Student. Journal of English language teaching. Vol 3. No 1. http://ejournal.unp.ac.id/index.php/jelt/a rticle/view/4303/3366 